\title{
BILATERAL PNEUMOTHORAX AS A COMPLICATION OF PERCUTANEOUS TRACHEOSTOMY: CASE REPORT
}

\author{
Tino Klancir ${ }^{1}$, Višnja Nesek Adam ${ }^{1,2}$, Viviana Mršić ${ }^{1}$, Damjan Marin ${ }^{1}$ and Tatjana Goranoviće, \\ ${ }^{1}$ Clinical Department of Anesthesiology, Resuscitation and Intensive Care, Sveti Duh University Hospital, Zagreb; \\ ${ }^{2}$ Osijek School of Medicine, Josip Juraj Strossmayer University, Osijek; ${ }^{3}$ Department of Anesthesiology and \\ Intensive Medicine, University Department for Tumors, Sestre milosrdnice University Hospital Centre, \\ Zagreb, Croatia
}

\begin{abstract}
SUMMARY - Percutaneous dilatational tracheostomy is a common surgical procedure that is becoming the method of choice in critically ill patients whenever prolonged airway secure and/ or ventilation support is needed. Although adverse events are relatively uncommon, serious life threatening complications can arise from this bedside procedure. We report a case of a 70-year-old female who developed extensive subcutaneous emphysema and bilateral pneumothorax immediately after a percutaneous dilatational tracheostomy procedure. Different mechanisms, such as damage to posterior or anterior tracheal wall, false passage or paratracheal placement or dislocation of the cannula are considered to be responsible for the development of pneumothorax and subcutaneous emphysema. Although bronchoscopic control after the tracheostomy procedure did not reveal any tracheal injury, we believe that subcutaneous emphysema and bilateral pneumothorax are most likely caused by procedure induced injuries of the trachea in addition to the applied high airway pressure induced by excessive or inappropriate ventilation. In our case report, we would like to emphasize that continuous bronchoscopic guidance during percutaneous tracheostomy is invaluable in decreasing the incidence of its overall complications, especially during enhancing the team experience.
\end{abstract}

Key Words: Tracheostomy-Methods; Acute Disease; Pneumothorax; Subcutaneous Emphysema; Case Reports

\section{Introduction}

Percutaneous dilatational tracheostomy (PDT) is a common surgical procedure that is becoming the method of choice for securing airway in critically ill patients who need prolonged ventilation support ${ }^{1,2}$. PDT is one of the most frequently performed procedures in intensive care units (ICU) and has become established as the alternative method over conventional surgical tracheostomy (ST) for long-term intubated patients. It was introduced as a preferred, safe and less-invasive bedside method that is alternative

Correspodence to: Assist. Prof. Višnja Nesek Adam, MD, PhD, Clinical Department of Anesthesioloy, Resuscitation and Intensive Care, Sveti Duh University Hospital, Sveti Duh, HR-10000 Zagreb, Croatia

E-mail: visnja.nesek@hotmail.com for open surgical tracheostomy. The rate of overall perioperative complications is $19 \%^{3}$. Although adverse events are relatively uncommon, serious life threatening complications can arise from this bedside procedure. Pneumothorax and subcutaneous emphysema are relevant but infrequent severe complications of PDT occurring in $0.8 \%$ and $1.4 \%$, respectively. Although in the literature there are several case reports, the occurrence of subcutaneous emphysema and bilateral pneumothorax is extremely rare ${ }^{4,5}$. We report a case of bilateral pneumothorax and subcutaneous emphysema due to tracheostomy.

\section{Case Report}

A 70-year-old woman $(61 \mathrm{~kg}, 168 \mathrm{~cm})$ with past medical history of advanced Alzheimer disease and 
arterial hypertension was admitted to the Trauma Ward due to luxation of the right hip partial endoprosthesis, one month after its insertion at our institution. Within 48 hours of admission to medical unit, she was transferred to our ICU due to sepsis, hypotension, tachycardia, low urine output and increased body temperature $\left(38.5^{\circ} \mathrm{C}\right)$ with a known urinary infection and auscultatory finding of right side pneumonia. In the ICU, central venous catheter and arterial line were placed and she was managed with oxygen supplementation, broad-spectrum intravenous antibiotics, intravenous fluid and vasopressor therapy. Chest $\mathrm{x}$-ray revealed a right lower lobe infiltrate with no evidence of pneumothorax. As the general condition of the patient improved, six days later under general anesthesia the prosthesis was removed. She was extubated 4 hours after the operation. Ten days later, she developed respiratory distress with tachypnea, tachycardia and bilateral wheezes. Arterial blood gas analysis revealed marked hypoxemia and chest x-ray showed new diffuse bilateral alveolar infiltrates (Fig. 1). The patient's arterial blood parameters were as follows: $\mathrm{pH} 7.42, \mathrm{pCO}_{2} 4.8, \mathrm{pO}_{2} 4.7$ BE-1 HCO3 23.6 $\mathrm{SatO}_{2} 69 \%$. She was intubated and placed on mechanical ventilation.

On day 15, we decided to perform percutaneous tracheostomy using Seldinger guidewire technique with single dilator $\left(\right.$ Portex $^{\circledR}$ with Blue line Ultra ${ }^{\circledR}$ ) to aid further management in the ICU with the prospect of prolonged ventilation. The procedure was performed by two anesthetists/intensivists and senior

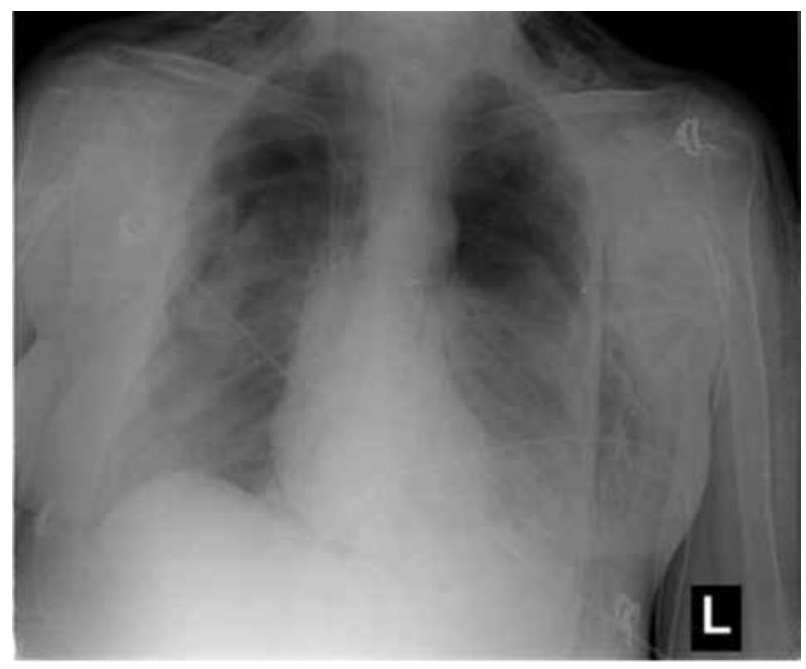

Fig. 1. Diffuse bilateral alveolar inflttrates. resident providing anesthesia and minding the airway.

Prior to performing the procedure with the patient already positioned and the neck extended, ultrasound was done to identify the structures such as thyroid and cricoid cartilages, blood vessels, tracheal midline, and the levels of tracheal cartilages. During PDT, the patient was ventilated using $100 \%$ oxygen, and received $100 \mu \mathrm{g}$ of fentanyl iv, $2 \mathrm{mg}$ iv of midazolam, propofol a $100 \mathrm{mg}$ iv and vecuronium bromide a $6.0 \mathrm{mg}$ iv. The neck was prepared with chlorhexidine and the area around the point of insertion of the tracheostomy was infiltrated with $5 \mathrm{~mL}$ of lidocaine $1 \%$ with epinephrine 1:200 000. After local infiltration, transverse incision was made through the skin and subcutaneous tissues. Using blunt dissection, the pretracheal fascia was exposed and the needle with the catheter was introduced into the trachea between the second and third tracheal rings. After introducing the catheter into the trachea, the guide wire was passed into the trachea and the needle was withdrawn. The dilator was passed with minor resistance over the guiding catheter and advanced into the trachea until the tip lay in the trachea. After two attempts, the size- 8 tracheostomy tube was finally inserted and the wire and guiding catheter were removed. Position was confirmed using capnography and chest auscultation. We did not use bronchoscopy to confirm the correct position of the guide wire and tube. Although end-tidal carbon dioxide trace was detected in the beginning with regular $\mathrm{CO}_{2}$ curve, ventilation became inadequate and peak inspiratory airway pressure (PIP) increased to $40 \mathrm{~cm} \mathrm{H}_{2} 0$. We immediately converted to ambu bag manual ventilation, however, severe resistance was experienced. Very soon thereafter, no visible chest rise was observed and on auscultation of the chest no breath sounds were heard. Subcutaneous emphysema started to appear rapidly at the face, neck and precordia, and as mentioned before, no breath sounds were heard. Re-intubation via the endotracheal route was immediately performed and the tracheostomy tube was removed. An ENT surgeon (otorhinolaryngologist) was also called for assistance. Tracheostomy site was explored by ENT surgeon and showed only insertion site between the second and third tracheal ring, with no evidence of bleeding and visible tracheal injury. After the patient's condition had stabilized, the tra- 


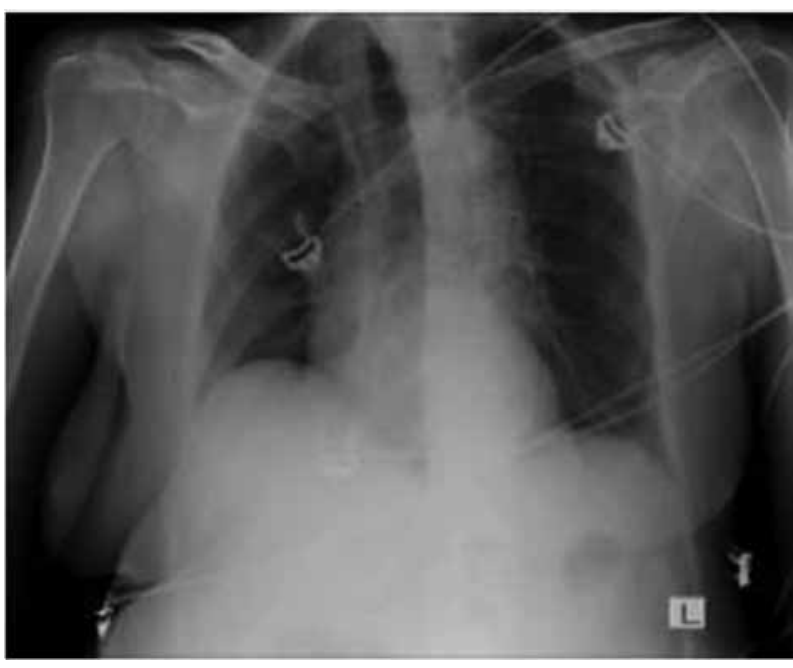

Fig. 2. Left side tension pneumothorax with mediastinal shift.

cheostomy tube was inserted without difficulty under direct vision. At the end of the procedure, fiberoptic examination was performed and no evidence of tracheal wall injury was found. Although subcutaneous emphysema was initially reduced, after one hour massive subcutaneous emphysema of the head, neck and thorax developed. ABG analysis revealed acute respiratory acidosis $\mathrm{pH} 7.123 \mathrm{pCO}_{2} 9.05 \mathrm{kPa}$ $\mathrm{pO}_{2} 10.2 \mathrm{kPa} \mathrm{BE}-7 \mathrm{HCO}_{3} 22.2 \mathrm{mmol} / \mathrm{L} \mathrm{SaO}_{2} 89 \%$. Immediate chest $\mathrm{x}$-ray revealed right-sided pneumothorax. A chest tube was placed immediately and the pneumothorax subsided. Two hours later, the patient developed severe hypoxemia and mild hypotension and bradycardia. Clinical assessment revealed absent breath sounds on the entire left side and immediate chest $\mathrm{x}$-ray revealed left side tension pneumothorax with mediastinal shift (Fig. 2). A chest tube was inserted and an immediate improvement in oxygen saturation was observed. Both tubes were attached to a water seal chest drainage system. Repeat chest $\mathrm{x}^{-}$ ray showed re-inflation of both lungs and confirmed the chest drain position in the pleural space (Fig. 3). The next day, the patient started showing signs of improvement and $\mathrm{ABG}$ analysis revealed $\mathrm{pH} 7.413$ $\mathrm{pCO}_{2} 4.89 \mathrm{kPa} \mathrm{pO}_{2} 8.49 \mathrm{kPa} \mathrm{BE}-0.1 \mathrm{HCO}_{3} 24.8$ $\mathrm{mmol} / \mathrm{L} \mathrm{SaO}_{2} 91 \%$.

Although there was improvement of respiratory status, the patient's general condition deteriorated despite ventilatory and hemodynamic support and she

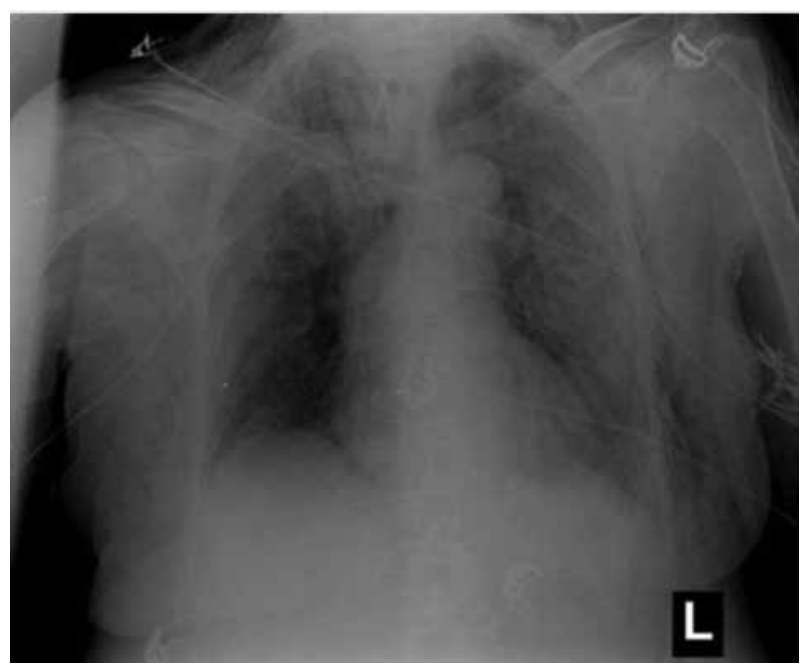

Fig. 3. Re-inflation of both lungs and confirmed chest drain position in the pleural space.

died from sepsis and multiple organ failure after 19 days at the ICU.

\section{Discussion}

Although very rare, there are several case reports of subcutaneous emphysema and bilateral pneumothorax. A similar case report has also been published in Croatia ${ }^{6}$. The pathophysiology of emphysema and pneumothorax during PDT has been investigated in cadaveric models. Various mechanisms have been postulated as the causes of emphysema development. These include malpositioning, misplacement or dislocation of tracheostomy tube, and high ventilatory pressures. Injury of the posterior tracheal wall, caused by the tip of the needle or the tip of the dilating forceps has also been reported as a cause of emphysema ${ }^{7,8}$. Even though subcutaneous emphysema is not always a symptom of pneumothorax, it should always be taken into consideration when subcutaneous emphysema occurs. The posterior tracheal injury, very low incision site or paratracheal placement of the initial needle puncture are the most often causes of pneumothorax. One mechanism involves direct injury to the pleura after perforation of the posterior tracheal wall, especially when the puncture site is lower than usual. The distance between the dorsal tracheal wall and the pleural cavity in cadaver model is approximately $5 \mathrm{~mm}$. A second theory suggests that air dissection 
through the cervical incision and peritracheally leads to pneumomediastinum, ultimately resulting in pneumothorax if the air ruptures into the mediastinal cavity. A rupture of an alveolar bleb could explain the third mechanism that results in pneumothorax ${ }^{9}$.

In our case, although bronchoscopic control after the tracheostomy procedure did not reveal any tracheal injury, we believe that subcutaneous emphysema and bilateral pneumothorax were most likely caused by injuries of the trachea and pleura with high airway pressure induced by excessive or inappropriate manual ventilation and positive pressure mechanical ventilation.

Namely, we hypothesized that following the tracheostomy procedure, bilateral pneumothorax was secondary to perforation of the posterior tracheal wall and puncture of the pleura. The pleura was accidentally opened, and some air had entered into the pleural space. Positive pressure ventilation induced further leak and progressive accumulation of air and accelerated the onset of pneumothorax. Also, the air accumulated in the pleural space was passed directly into the subcutaneous tissue resulting in emphysema. As the air accumulated in the pleural space and increased subcutaneous tissue pressure responsible for widespread emphysema, intrapleural pressures increased and exceeded atmospheric pressure, creating tension pneumothorax. If $\mathrm{x}$-ray or better computed tomography or magnetic resonance imaging had been done after re-intubation and tracheal tube removal and prior to the tracheal tube re-insertion, the complications would not have probably been so dramatic.

As we mentioned before, although adverse events following PDT are relatively uncommon, complications such as pneumothorax and subcutaneous emphysema can arise from this bedside procedure ${ }^{4,5}$. The routine use of bronchoscopic guidance for PDT is controversial and high-level evidence from well-designed studies is lacking. Some authors documented fiberoptic bronchoscopy to affect gas exchange retaining carbon dioxide, to decrease partial oxygen tension, to raise intracranial pressure due to the increase in partial carbon dioxide tension, and to increase the length of time of the procedure ${ }^{10,11}$. On the other hand, routine use of fiberoptic bronchoscope has been shown to reduce the incidence of complications and several studies advocate its routine use ${ }^{12,13}$. For this reason, nowadays, most institutions routinely perform the procedure under bronchoscopic guidance.

Prior to performing the procedure with the patient already positioned and the neck extended, we usually used ultrasound to identify the structures such as blood vessels close to the intended site of tracheostomy, the thyroid and cricoid cartilages, and the first three tracheal rings. Although the literature does not convincingly support using ultrasound routinely, but rather as an adjunct in selected patients, several studies and our personal experience have shown that ultrasound performed prior to percutaneous tracheostomy may be useful in avoiding injury to pretracheal vascular structures and in avoiding high placement of the tube ${ }^{14,15}$.

Ultrasound examination performed before the procedure and fiberoptic bronchoscopy during the procedure can decrease complication rates and improve the safety of $\mathrm{PDT}^{15}$. Unfortunately, we did not use bronchoscopy in our patients.

In conclusion, we would like to point out that PDT may cause life-threatening complications and intensivists should always be vigilant to recognize it. Also, it is very important to emphasize that bronchoscopic guidance during percutaneous tracheostomy is invaluable, as it may help decrease the incidence of overall complications.

\section{References}

1. Friedman Y, Fields J, Mizock B, Samuel J, Patel S, Appavu $\mathrm{S}$, et al. Comparison of percutaneous and surgical tracheostomies. Chest. 1996;110(2):480-5.

2. Levin R, Trivikram L. Cost/benefit analysis of open tracheostomy, in or at the bedside, with percutaneous tracheostomy. Laryngoscope. 2001;111(7):1169-73.

3. Hill BB, Zweng TN, Maley RH, Charash WE, Toursarkissian B, Kearney PA. Percutaneous dilational tracheostomy: report of 356 cases. J Trauma. 1996 Aug;41(2):238-43; discussion 243-4.

4. Won HK, Byoung HK. Bilateral pneumothoraces, pneumomediastinum, pneumoperitoneum, pneumoretroperitoneum, and subcutaneous emphysema after percutaneous tracheostomy - a case report. Korean J Anesthesiol. 2012;62(5):488-92. doi: 10.4097/kjae.2012.62.5.488

5. Stupnik T, Steblaj, S, Sok M. Major tracheal tear and bilateral tension pneumothorax complicating percutaneous tracheostomy. Arch Otolaryngol Head Neck Surg. 2009;135(8):8213. doi: 10.1001/archoto. 2009.88

6. Bartolek D, Somun N, Bartolek F, Zdravčević-Šakić K, Lajt- 
man Z, Banić T, et al. Life-threatening complication after PDT. Coll Antropol. 2009;33(4):1409-13.

7. Fikkers BG, van Veen JA, Kooloos JG, Pickkers P, van den Hoogen FJ, Hillen B, et al. Emphysema and pneumothorax after percutaneous tracheostomy: case reports and an anatomic study. Chest. 2004;125(5):1805-14.

8. Kaylie DM, Wax MK. Massive subcutaneous emphysema following percutaneous tracheostomy. Am J Otolaryngol. 2002;23:300-2. doi:10.1053/ajot.2002.124192

9. Berg LF, Mafee MF, Campos M, Applebaum EL. Mechanisms of pneumothorax following tracheal intubation. Ann Otol Rhinol Laryngol. 1988;97(5 pt 1):500-5. doi: 10.1177/000348948809700512

10. Al-Ansari M, Hijazi H. Clinical review: percutaneous dilatational tracheostomy. Crit Care. 2006;10:202. doi: 10.1186/ cc3900

11. Reilly PM, Anderson III HL, Sing RF, Schwab CW, Bartlett RH. Occult hypercarbia: an unrecognized phenomenon during percutaneous endoscopic tracheostomy. Chest. 1995;107:1760-3. doi:10.1378/chest.107.6.1760
12. Kornblith LZ, Burlew CC, Moore EE, Haenel JB, Kashuk $\mathrm{JL}$, Biffl WL, et al. One thousand bedside percutaneous tracheostomies in the surgical intensive care unit: time to change the gold standard. J Am Coll Surg. 2011;2:163-70. doi: 10.1016/j.jamcollsurg.2010.09.024

13. Fernandez L, Norwood S, Roettger R, Gass D, Wilkins H. Bedside percutaneous tracheostomy with bronchoscopic guidance in critically ill patients. Arch Surg. 1996;131(2):129-32. doi:10.1001/archsurg.1996.01430140019005

14. Šustić A, Kovač D, Zgaljardić Z, Župan Ž, Krstulović B. Ultrasound-guided percutaneous dilatational tracheostomy: a safe method to avoid cranial misplacement of the tracheostomy tube. Intens Care Med. 2000;26:1379-81. doi: 10.1007/ s001340000589

15. Kollig E, Heydenreich U, Roetman B. Ultrasound and bronchoscopic controlled percutaneous tracheostomy on trauma ICU. Injury. 2000;31:663-8. doi: 10.1016/S00201383(00)00094-2

\section{Sažetak \\ OBOSTRANI PNEUMOTORAKS KAO KOMPLIKACIJA PERKUTANE TRAHEOTOMIJE: PRIKAZ SLUČAJA}

\section{T. Klancir, V. Nesek Adam, V. Mršić, D. Marin i T. Goranović}

Perkutana dilatacijska traheotomija je učestali kirurški zahvat koji postaje metodom osiguravanja dišnoga puta u kritičnih bolesnika i bolesnika na dugotrajnoj mehaničkoj ventilaciji. Iako su popratni učinci relativno rijetki, metoda je vezana uz mogućnost nastanka za život opasnih komplikacija. Prikazujemo slučaj 70-godišnje žene kod koje je došlo do razvoja opsežnog potkožnog emfizema i obostranog pneumotoraksa neposredno nakon izvođenja perkutane traheotomije. Različiti mehanizmi kao što su oštećenje stražnjeg ili prednjeg zida dušnika, lažni prolaz ili paratrahealno postavljanje ili dislokacija kanile mogu se smatrati odgovornim za nastanak pneumotoraksa i potkožnog emfizema. U našem prikazu slučaja, iako nakon perkutane traheotomije bronhoskopskim pregledom nije nađeno oštećenje dušnika, smatramo da je uzrok nastanka potkožnoga emfizema i obostranog pneumotoraksa najvjerojatnije procedurom nastala ozljeda dušnika i primjena visokog tlaka u dišnim putovima izazvanog prejakom ili neodgovarajućom ventilacijom. Ovim prikazom slučaja željeli bismo naglasiti važnost bronhoskopske vizualizacije tijekom izvođenja perkutane traheotomije u prevenciji nastanka mogućih komplikacija, osobito u razdoblju usvajanja ove kliničke vještine.

\footnotetext{
Ključne riječi: Traheotomija - metode; Akutna bolest; Pneumotoraks; Potkožni emfizem; Prikazi slučaja
} 